Jurnal Info Kesehatan

Vol.17, No.2, December 2019, pp.152-160

P-ISSN 0216-504X, E-ISSN 2620-536X

DOI: 10.31965/infokes. Vol17.Iss2.307

Journal homepage: http://jurnal.poltekeskupang.ac.id/index.php/infokes

\title{
Effects of Bibliotherapy and Snake-Ladder Game's Therapy on the Cooperative Level of Children during Hospitalization
}

\author{
Rahmah Widyaningrum ${ }^{1 a^{*}}$, Ignasia Nila Siwi ${ }^{1 b}$ \\ ${ }^{1}$ STIKes Madani Yogyakarta, Indonesia. \\ ${ }^{a}$ Email address: rahmah.widyaningrum@gmail.com \\ b Email address: ignasiasiwi@gmail.com
}

Received: 10 November 2019 Revised: 30 December 2019 Accepted: 30 December 2019

\begin{abstract}
Children who were hospitalized in 2017 were $3.21 \%$ with the percentage of school-age children $47.62 \%$. Hospital is a planned or emergency process where children are required to undergo treatment at the hospital. The reaction of child hospitalization varies, depending on the stage of development, previous illness experiences, support systems, and the children's coping abilities. One of the stressors of pediatric hospitalization is the complexity of the therapeutic procedures provided by nurses and medical teams. The study aims to play therapy as one method in reducing anxiety and increasing children's cooperation during undergoing treatment procedures. The research method was Pre-Experimental Research with One Group Pretest-Posttest approach. A sample of 20 children was with a simple random sampling technique. The study was conducted in April-September 2019 in the Children's Ward of Yogyakarta City Public Hospital. Inclusion criteria: children were first admitted to the hospital on the first or second day; children aged 7-12 years; had no physical disabilities, cognitive and language disorders; had sufficient physical ability to take part in the game. The results of data analysis using paired t-test obtained $p$-value $<0.001$ with a pretest value of $16.55 \pm 6.88$ and post-test $26.45 \pm 1.79$. The conclusion of the research shows that there is an effect of giving Bibliotherapy and SnakeLadder Game Therapy in increasing the cooperative level of children in undergoing nursing actions during hospitalization. Researchers recommend this play therapy as one of the permanent procedures for independent nursing actions in each child's ward.
\end{abstract}

Keywords: Snake-ladder game's therapy, hospital

\footnotetext{
*Corresponding Author:

Rahmah Widyaningrum,

STIKes Madani Yogyakarta,

Veteran Street, No. 100, RT 29/RW 07, Warungboto, Umbulharjo, Yogyakarta, Indonesia.

Email: rahmah.widyaningrum@gmail.com

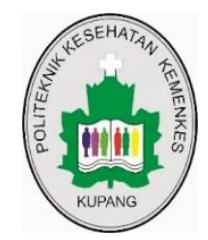

(CThe Author(s) 2019. This article is distributed under the terms of the Creative Commons Attribution 4.0 International License (http://creativecommons.org/licenses/by/4.0/), which permits unrestricted use, distribution, and reproduction in any medium, provided you give appropriate credit to the original author(s) and the source, provide a link to the Creative Commons license, and indicate if changes were made. The Creative Commons Public Domain Dedication waiver (http://creativecommons.org/publicdomain/zero/1.0/) applies to the data made available in this article, unless otherwise stated.
} 


\section{INTRODUCTION}

Based on Susenas data 2017, children aged 0-17 years who experienced health complaints and hospitalization in the Hospital in 2017 were 3.21\% (Kementerian Pemberdayaan Perempuan dan Perlindungan Anak dengan Badan Pusat Statistik, 2018). Preschool and school age children are vulnerable to disease. Hospitalization is a planned or emergency process that requires children to stay in the hospital and undergo therapy and treatment until returning home (Hockenberry, M.J \& Wilson, D, 2013). Hospitalization can be a threatening and stressful experience for children. Being unfamiliar with the environment and medical procedures and unaware of the reasons for being hospitalized, it can cause children to be insecure, uncertain, anxious, and feeling helpless. Anxiety is the most commonly reported from negative responses, and high levels of anxiety can apply to children's physiological and psychological health. Excessive anxiety also impedes children's efficacy in coping with medical care, and increases their operative behavior and negative emotions towards health care professionals (Costa Fernandes \& Arriaga, 2010).

The results of a study of 252 children who were hospitalized in Mexico said that the mean of children aged 10.1 years received 1.82 invasive nursing actions per child, of whom $77.8 \%$ were reported to cause stress. These procedures include: $46.3 \%$ infusion, $20.1 \%$ clinical examination, and venous blood sampling 10.8\% (Ortiz et al., 2012). The role of nurses is to prepare children to deal with anxiety, have a cooperative attitude, have good coping skills and facilitate self-control when experiencing cases that cause stress (Hockenberry, M.J \& Wilson, D. 2013). Children who are hospitalized have less control over the settings and medical procedures they receive. Moreover, both of these are the main sources of stress, so that it can cause substantial anxiety among children who are hospitalized (Li et al., 2011).

The prevention of anxiety in children due to hospitalization can be conducted with several techniques. Playing therapy using hospital medical devices, such as bandages, syringes, roentgen photos, etc. makes the children know the name and understand the function of the tool. Various types of therapeutic games provide stimulus to children to laugh, express their play, and divert children from discussing their illness conditions (Huerga et al., 2016). According to (Koukourikos et al., 2015) forms of therapeutic games such as play therapy are proven to have high therapeutic value for sick and hospitalized children. It contributes to the physical and emotional well-being of the child's recovery process. In addition, it can help to investigate problems related to the child's experience of being hospitalized and reduce the intensity of negative feelings that accompany during hospitalization. Play is widely used in pre-operative preparations and invasive procedures, as well as for children with cancer. Antoher study (Patel, V, \& H.N, 2014) in Vadodara, India shows that anxiety levels are reduced or become anxious after participating in play therapy activities.

Bibliotherapy is a therapy using books to support the needs of children to process difficult or painful personal experiences, the opportunity for children to explore events that are almost the same as events experienced with different versions so that children are not too focused on events (Hockenberry, M.J \& Wilson, D, 2013). Bibliotherapy will bring about the cathartic effect by releasing a feeling of fear so it may provide a sublime effect in the form of peace and well-being (Rocha et al., 2016).

Based on a preliminary study in the Children's Ward of Yogyakarta City Hospital of parents with children being treated, parents conveyed their children are cooperative about treatment procedures, both drug injection and infusion. Meanwhile, other parents 
said that children become fussy, more spoiled, hysterical, crying or pulling on their mother's clothes when an action was taken. The approach to overcoming a child's anxiety about nursing procedures must be specific, which is it is adapted to the stages of physical-motor development, cognitive, language, emotion, social, and religion. Bibliotherapy and Snake Ladder Game's Therapy facilitate the need for games with peers that occur in the development of school-age children. The game is modified according to the child's needs for positive self-concept during hospitalization, thus, forming constructive coping with stress. This play therapy consists of 2 sessions, 30-45 minutes duration in each session. Therapy is conducted by nurses accompanied by parents, where parents participate to assist during the game process. The design of the ladder snake is attractively packaged both in terms of the picture as well as positive writing content. A bibliotherapy card is provided to stimulate a child to make a complaint, feel discomfort, and find a solution to be picky during treatment procedures.

\section{RESEARCH METHOD}

This research is a Pre-Experimental Design with One Group Pretest-Posttest approach. The study was conducted in a children's ward at Public Hospital of Yogyakarta City, Wirosaban St. Number 1 Yogyakarta. Sampling technique used simple random sampling method with the number of samples in the intervention group of 20 school-age children. The inclusion criteria set by the researchers were as follows: the child was treated for the first time in the hospital and the first or second day of hospital admission; children aged 7-12 years; Muslim, do not have physical disabilities, cognitive and language disorders; have sufficient physical ability to take part in the game; children are willing to be respondents and follow the research until the end. The exclusion criteria were as follows: the child had been treated $>2$ times in the same or different hospitals; children experience conditions: severe pain, high fever, moderate to severe dehydration, or get therapy through a nasogastric tube (NGT). This research was conducted after obtaining ethical eligibility with Number 791/KEP-UNISA/VI/2019.

The intervention of playing therapy of Bibliotherapy and Snake and Ladder Game's Therapy was implemented for two sessions, each session lasting for 30-45 minutes. Therapeutic facilitators are nurses with assistance from parents in each session. Session one with the next session is held on different days according to the time contract between the nurse and the child. The research instruments were a set of ladder snake games and bibliotherapy; and an observation sheet to assess the cooperative level of the child during the treatment action. The snake and ladder game set consists of a special design snake and ladder drawing board, a large dice, a cup to shake the dice, a running pin, and a bibliotherapy card. The design of the snake ladder board consists of a positive statement for the 'ladder' path and a negative statement for the 'snake' path. Positive statements are associated with Islamic beliefs, for example: Pain is from God; I am patient with my pain; Allah reward me; I obey the doctors and nurses' parents; and so forth. Meanwhile, an example of a negative statement is as follows: I don't want to take medicine; I cried and refused to be examined; and others. The observation sheet consists of 4 assessment topics, which are: the child's behavior when the nurse invites conversation or talks; the behavior of the child when the nurse arrives by bringing care tools; the behavior of the child when the nurse performs the examination or treatment procedure, and the behavior of the child when the nurse orders something as one of the treatment procedures. Data were analyzed using paired t test. 
Widyaningrum, R., \& Siwi, I. N. (2019). Effects of Bibliotherapy and Snake-Ladder Game's Therapy on the Cooperative Level of Children during Hospitalization. JURNAL INFO KESEHATAN, 17(2), 152-160. https://doi.org/10.31965/infokes.Vol17.Iss2.307

\section{RESULTS AND DISCUSSION}

Table 1. Characteristics of School-Aged Respondents treated at Public Hospital of Yogyakarta City $(\mathrm{n}=20)$

\section{Characteristic}

Frequency (n) Percentage $(\%)$

1. Age

\begin{tabular}{lrr}
\hline $7-9$ years & 12 & 60 \\
\hline $10-12$ years & 8 & 40 \\
\hline 2. Sex & 12 & 60 \\
\hline Male & 8 & 40 \\
\hline Female & 7 & \\
\hline 3. Medical Diagnosis & 3 & 35 \\
\hline Febris & 2 & 15 \\
\hline Fracture & 1 & 10 \\
\hline Thypoid & 1 & 5 \\
\hline DHF & 1 & 5 \\
\hline Asthma & 1 & 5 \\
\hline Diarrhea & 4 & 5 \\
\hline Appendicitis & 4 & 20 \\
\hline Others & & \\
\hline
\end{tabular}

4. Nursing Action

\begin{tabular}{lrr}
\hline Infusion & 13 & 65 \\
\hline Bandage and sling & 3 & 15 \\
\hline Nebulisation & 1 & 5 \\
\hline Wound treatment & 1 & 5 \\
\hline Others & 2 & 10 \\
\hline
\end{tabular}

5. Length of inpatient

\begin{tabular}{lll}
\hline 3 days & 9 & 45 \\
\hline 4 days & 8 & 40 \\
\hline 5 days & 3 & 15 \\
\hline 6. Pars
\end{tabular}

6. Parents who wait

\begin{tabular}{lrr}
\hline Mother & 15 & 75 \\
\hline Father & 5 & 25 \\
\hline
\end{tabular}

The results of this study stated that the majority of respondents aged 7-9 years were 12 people $(60 \%)$ with the majority of male sex 12 people $(60 \%)$. Children who have a younger age tend to be more prone to stress due to the immature level of development, low adaptability, and high levels of dependency with parents. According to (A'diilah \& Somantri, 2016), effective storytelling therapy reduces anxiety scores in toddler and pre-school age children. It is related to the process of growth and development of preschoolers who are able to reframe messages better than toddler age, where preschoolers give meaning to the fairy tales given by nurses. During hospitalization children experience separation from family, being in a foreign environment, and must undergo several nursing or medical procedures. Many reactions arise due to the situation. Specifically, reactions that arise are influenced by age of development, previous experience with the disease, separation, hospitalization, coping skills possessed, the severity of the diagnosis, and the existing support system 
(Hockenberry, M.J \& Wilson, D, 2013).

Boys tend to be more prone to stress from hospitalization due to several factors, including: attachment to high peer groups or limitations in moving and playing. It is different from the results of the study which stated that the characteristics of toddler and preschool respondents in the Children's Room of the Hospital have the same gender frequency, consisting of $46.7 \%$ boys and $53.3 \%$ girls. It is indicated that gender does not have a major effect on the stress of hospitalization (A'diilah \& Somantri, 2016). Stress during hospitalization is found more in the age group $\geq 10$ years while less in the age group 8-10 years. Stress levels in boys $(30.4 \pm 3.7)$ are higher than girls $(29.6 \pm 2.7)$ but there is no significant relationship between stress levels and gender (Karn, et al., 2018).

The results showed the majority of children treated in the hospital were diagnosed with febrile observation of 7 people (35\%). Febris or fever is a symptom of acute illness, where the most nursing action received by children is the administration of drugs through infusion of 13 people (65\%), with a maximum length of stay of 3 days $(45 \%)$. Similar study (Commodari, 2010) stated that $55 \%$ of pediatric patients experience respiratory diseases, $30 \%$ by gastrointestinal pathology, $9 \%$ allergic reactions and $11 \%$ other pathologies. Other studies show that with increasing duration of illness, stress levels of children also increase but there was no significant relationship between children's stress levels and duration of illness in children aged between 3 to 8 years. Research shows that the level of severe stress in children who are chronically ill is $79 \%$ while children who are acutely ill are $61.89 \%$. Chronically, ill children have more stress than children with acute illness (Karn dkk., 2018). The length of stay affects the perception of stress and anxiety levels. 172 children were hospitalized for 1-5 days, 35 children were treated for 6-10 days, 8 children for 11-15 days and 4 children were treated for $>16$ days. ANOVA analysis results showed significant differences in nurses' perceptions about stress but not in anxiety. Length of stay of $>16$ days results in a significant increase in stress compared to shorter stays (Commodari, 2010). The length of inpatient time has an influence on a child's anxiety score. The longer he is treated, the lower the anxiety score will be (A'diilah \& Somantri, 2016). During the first three days of being hospitalized, children experience a decrease in stress levels with increasing duration of stay. More than half of children (65.2\%) undergo hospitalization $<3$ days. The majority $(73.82 \%)$ of children have a disease duration $<8$ days (Karn et al., 2018).

In this study, the majority of children treated were attended by the mother of the child, which was 75\%. Based on research (Commodari, 2010), caregivers accompany children at night and for almost 6 hours during the day at the hospital. The study involved 219 caregivers, with 19 men and 200 women, with an average age of 32 years. Where 179 caregivers are mothers of children who live in hospitals, 18 are fathers, 5 are brothers or sisters, 17 are other siblings (grandmothers or aunts).

Table 2. Characteristics of Respondent Parents treated at Public Hospital of Yogyakarta City $(n=20)$

\begin{tabular}{lrr}
\hline \multicolumn{1}{c}{ Characteristic } & Frequency & Percentage (\%) \\
\hline 1. Sex & & \\
\hline Male & 5 & 25 \\
\hline Female & 15 & 75 \\
\hline 2. Education & & 5 \\
\hline Elementary School & 1 & 25 \\
\hline Junior High School & 5 & 70 \\
\hline Senior High School & 14 & \\
\hline
\end{tabular}


Widyaningrum, R., \& Siwi, I. N. (2019). Effects of Bibliotherapy and Snake-Ladder Game's Therapy on the Cooperative Level of Children during Hospitalization. JURNAL INFO KESEHATAN, 17(2), 152-160. https://doi.org/10.31965/infokes.Vol17.Iss2.307

\begin{tabular}{lrr}
\hline 3. Occupation & & \\
\hline Housewife & 8 & 40 \\
\hline Laborer & 2 & 10 \\
\hline Employee & 8 & 40 \\
\hline Entrepreneur & 1 & 5 \\
\hline Indonesian Army & 1 & 5 \\
\hline 4. Number of children & 2 & 10 \\
\hline 1 & 10 & 50 \\
\hline 2 & 8 & 40 \\
\hline 3 & & \\
\hline 5. Experience in taking care of children & 14 & 70 \\
\hline Yes & 6 & 30
\end{tabular}

Based on table 2, most have the latest high school education equal to 14 people $(70 \%)$ and the majority of respondents' parents have experience caring for sick children beforehand as many as 14 people (70\%). it is consistent with research (Commodari, 2010) which stated the educational background of parents waiting for children to be hospitalized is $7.9 \%$ have primary school level education, $47.9 \%$ have junior high school level education, $32.4 \%$ have a high school level education, and $12.3 \%$ have a bachelor's degree or diploma. Based on table 2, the results show that the majority of respondents' majority parents have 2 children as many as 10 people (50\%). Other studies have shown that with an increase in the number of siblings, stress levels will decrease $(31.1 \pm 3.2$ to $28.3 \pm 3.3)$ so that there is a significant relationship with $\mathrm{p}$ value $=0.01$ between stress levels and the number of siblings biological children treated at the hospital (Karn et al., 2018).

The results of statistical analysis using paired sample t-test showed a significant difference between before and after the intervention of Bibliotherapy and Snake and Ladder Game's Therapy on the improvement of cooperative attitudes in school-age children in undergoing nursing actions in Anggrek and Bougenvile Ward of Public Hospital, Yogyakarta City. After 2 days of intervention, there was a significant increase ( $p$ value $<0.001$ ) towards the child's cooperative level. It shows that the intervention in the form of Bibliotherapy and Snake and Ladder Game's Therapy is effectively able to improve the cooperative attitude of children in undergoing nursing actions at Public Hospital of Yogyakarta City.

Tabel 3. Pengaruh Bibliotherapy dan Snake Ladder Game's Therapy terhadap Tingkat Kooperatif Anak dalam menjalani Tindakan Keperawatan di RSUD Kota Yogyakarta $(\mathrm{n}=20)$

\begin{tabular}{cclc}
\hline Variable & Pre-test & Post-test & p-value \\
\hline Level of Children's cooperativeness & $16,55 \pm 6,88$ & $26,45 \pm 1,79$ & $<0.001$ \\
\hline
\end{tabular}

Anxiety experienced by children during nursing action is influenced by anxiety hospitalization. Anxious phases include: 1) the protest phase, shown by the child's reaction to crying, screaming, looking for and holding on tightly to parents, refusing to meet and attack people who are not well known verbally or physically; 2) the desperate phase is characterized by the child being inactive, withdrawing from others, sad, not interested in the environment, not communicative, and refusing to eat or drink; 3) the 
acceptance phase, the child begins to show an interest in the environment and short interactions with other people or nurses (Hockenberry, M.J \& Wilson, D, 2013).

Research of (A'diilah \& Somantri, 2016) showed that during the second visit for three minutes in the administration of storytelling therapy, nurses used assistive devices in the form of hand puppets in the form of animals. Then, the nurse provided action, in this case, the administration of drugs through an IV line to the respondent and the researcher observes the anxiety score of the respondent and records it on the observation sheet. According to (Li et al., 2016) children who received play therapy interventions in hospitals showed fewer negative emotional experiences and lower anxiety levels than children who received usual care. Meanwhile, according to (Hockenberry, M.J \& Wilson, D, 2013), on the first day the child is hospitalized, the child is in the first phase, the protest phase. Children still do not feel comfortable in the hospital. They reject the fact that they must be in the hospital by receiving various kinds of therapy. Moreover, they have to adapt to the environment, routines, and new people. No friends who are there to invite to play, but nurses and other medical teams who often come to visit them and provide a variety of stressful procedures. It indicates that the child has not gone through the adaptation phase to reach the acceptance stage, because this acceptance stage usually occurs after the child has been hospitalized for several days or over a period of more than three days, and each child has a different adaptation time.

Qualitative research results indicate that the snake ladder method could improve cognitive performance in junior high school children in Selangor, Malaysia who have difficulty learning mathematics (Nachiappan et al., 2014). The application of the reading club method which includes reading aloud (bibliography) and illustrations can improve concentration, reduce anxiety and self-confidence of pediatric patients in the hospital (Selin, E. and Graube K., 2017). The application of CBT (cognitive behavior therapy), one of which is a therapy to play with snakes and ladders, read stories and analogies in children aged 5-14 years with speech disorders can reduce anxiety, low mood and improve self-confidence and communication at the center of Michael Palin (Kelman \& Wheeler, 2015).

A review of several journal articles shows that the administration of bibliographic therapy can increase self-confidence, acceptance of reality, psychological well-being and facilitate communication between health workers and pediatric patients treated in hospitals (Vélez \& Prieto, 2018). A review of the literature reports that the use of board media such as chess and others can improve cognitive, prevent depression and behavior modification (Nakao, 2019). According to (Moore et al., 2015), types of play therapy such as medical therapy are used for reducing children's pain and distress during medical treatment. In this study, children treated at burn clinics experienced less difficulty during dressing than those who received standard preparations. Children who received standard care reported a 2-point increase in pain during the procedure while children who participated in medical therapy reported an increase of 1 point. Parent satisfaction was higher for dressing treatment with medical therapy techniques than standard preparation.

\section{CONCLUSION}

Bibliotherapy and Snake Ladder Game's Therapy as one type of play therapy has a significant influence in improving children's cooperative behavior in following nursing actions during hospitalization. Researchers provide recommendations that this play therapy can be used as one of the permanent procedures for independent nursing in all children's wards in the hospital. 
Widyaningrum, R., \& Siwi, I. N. (2019). Effects of Bibliotherapy and Snake-Ladder Game's Therapy on the Cooperative Level of Children during Hospitalization. JURNAL INFO KESEHATAN, 17(2), 152-160. https://doi.org/10.31965/infokes.Vol17.Iss2.307

\section{REFERENCES}

A'diilah, N., \& Somantri, I. (2016). Efektifitas Terapi Mendongeng terhadap Kecemasan Anak Usia Toddler dan Prasekolah Saat Tindakan Keperawatan. Jurnal Keperawatan Padjadjaran, 4(3). 248-154.

Commodari, E. (2010). Children staying in hospital: a research on psychological stress of caregivers. Italian journal of pediatrics, 36(1), 1-9. https://doi.org/10.1186/1824-7288-36-40

Costa Fernandes, S., \& Arriaga, P. (2010). The effects of clown intervention on worries and emotional responses in children undergoing surgery. Journal of Health Psychology, 15(3), 405-415. https://doi.org/10.1177/1359105309350231

Hockenberry, M. J., \& Wilson, D. (2013). Wong's Essentials of Pediatric Nursing: Wong's Essentials of Pediatric Nursing. Elsevier Health Sciences.

Huerga, R. S., Lade, J., \& Mueller, F. (2016). Designing play to support hospitalized children. In Proceedings of the 2016 Annual Symposium on Computer-Human Interaction in Play (pp. 401-412).

Karn, B. K., Yadav, U \& Chaudhary, R. (2018). Effectiveness of play therapy in reducing stress among school age children admitted in paediatric wards of BPKIHS. Advance Research Journal of Multidiciplinary Discoveries, 21(1), 1316.

Kelman, E., \& Wheeler, S. (2015). Cognitive Behaviour Therapy with children who stutter. Procedia - Social and Behavioral Sciences, 193, 165-174. https://doi.org/10.1016/j.sbspro.2015.03.256

Kementerian Pemberdayaan Perempuan dan Perlindungan Anak dengan Badan Pusat Statistik. (2018). Profil Anak Indonesia 2018. Kementerian Pemberdayaan Perempuan dan Perlindungan Anak (KPPPA).

Koukourikos, K., Tzeha, L., Pantelidou, P., \& Tsaloglidou, A. (2015). The importance of play during hospitalization of children. Materia socio-medica, 27(6), 438-441.

Li, W. H., Chung, J. O., Ho, E. K., \& Chiu, S. Y. (2011). Effectiveness and feasibility of using the computerized interactive virtual space in reducing depressive symptoms of Hong Kong Chinese children hospitalized with cancer. Journal for Specialists in Pediatric Nursing, 16(3), 190-198.

Li, W. H., Chung, J. O. K., Ho, K. Y., \& Kwok, B. M. C. (2016). Play interventions to reduce anxiety and negative emotions in hospitalized children. BMC pediatrics, 16(1),1-9.

Moore, E. R., Bennett, K. L., Dietrich, M. S., \& Wells, N. (2015). The Effect of Directed Medical Play on Young Children's Pain and Distress During Burn Wound Care. Journal of Pediatric Health Care, 29(3), 265-273. https://doi.org/10.1016/j.pedhc.2014.12.006

Nachiappan, S., Rahman, N.A., Andi H., Zulkafaly, M. (2014). Snake and Ladder Games in Cognition Development on Students with Learning Difficulties. Review of Arts and Humanities, 3((2)), 217-229.

Nakao, M. (2019). Special series on "effects of board games on health education and promotion" board games as a promising tool for health promotion: A review of recent literature. BioPsychoSocial Medicine, 13(1), 5. https://doi.org/10.1186/s13030-019-0146-3 
Ortiz, M. I., López-Zarco, M., \& Arreola-Bautista, E. J. (2012). Procedural pain and anxiety in paediatric patients in a Mexican emergency department. Journal of advanced nursing, 68(12), 2700-2709.

Patel, K., Suresh, V., \& Ravindra, H. (2014). A study to assess the effectiveness of play therapy on anxiety among hospitalized children. IOSR Journal of Nursing and Health Science, 3(5), 17-23.

Rocha, R., Pereira, E., Silva, R., Bulnes, A., Sora, A., \& da Cunha, S. (2016). The Bibliotherapy in the Humanization of Care: Contributions to Nursing Practice. International Archives of Medicine, 9 (274).1-7

Selin, E. dan Graube K. (2017). Reading aloud to children in hospital. Bibliotherapy as a community Builder. IFLA WLIC.

Vélez, I. B., \& Prieto, J. L. (2018). Literature as a therapeutic instrument in the healthdisease process in childhood. Enfermería Global, 17(2), 601-616. 